\title{
Repositioning School Libraries towards Attainment of Learning without Borders
}

\author{
Emmanuel U. Anyanwu, Ph.D. \\ Emmanuel A. Oduagwu \\ Oyemike Victor Benson \\ Federal Polytechnic, Nekede, Owerri, Nigeria \\ Charles Obichere, Ph.D. \\ Federal Polytechnic, Nekede, Owerri, Nigeria
}

\begin{abstract}
The internet has revolutionized the global world system. Every aspect of the globe is under the influence of information and communication technologies. The educational sector is experiencing a paradigm shift towards a borderless economy and school libraries occupy a central place in the actualization of sustainable education. The paper highlights the need to reposition school librarianship to ensure actualization of learning without borders, the significance of school libraries in learning without borders agenda. Repositioning of school libraries requires addressing personnel issues, ICT-related issues, funding, extensive lobbying and advocacy, partnership with NGOs and stakeholders in educational sector, recruitment of qualified library staff and re-training of existing school library staff to meet global realities.
\end{abstract}

\section{Keywords: Advocacy, ICTs, School Librarianship, Personnel}

\section{INTRODUCTION}

School library is an independent organ that provides all the resources for the child's proper educational growth (Attama, 2004). IFLA school library guideline (2015) defines school library as a schools physical and digital learning space where reading, inquiry, research, thinking, imagination and creativity are central to students' information-to-knowledge journey and to their personal social and cultural growth. This physical and digital place is known by several terms (e.g school media centre, centre for documentation and information and library learning commons, but school library is the term most commonly used and applied to the facility and functions.

School library is also known as media resource centre, media centre, learning resource centre, multimedia centre, school media centre among others. Irrespective of the variety of names, a school library is information resources centre found in primary, secondary and teacher training colleges. It is an information centre established in the school environment and it is expected to provide information services for teaching and learning in the schools. The school library not only provides information materials but also provides guidance and a conducive atmosphere for teaching and learning.

Harrods Librarians Glossary (2005) sees a school library as an organized collection placed in a school for the use of teachers or pupils but usually for pupils. It may comprise of books and other materials, electronic resources and personal computers and be in the care of professional librarians, teacher, or teacher librarian. The school library act as a galvanizing force that leads to the provision of quality education. It is an inexhaustible information resource where teachers, pupils can go unrestricted to have access to information they need (George, 2011). Freeman (1975) summed up the goal of the school media centre as service offering members of the community, learning experiences that will lead them towards a fuller and more rewarding life. 
In the $21^{\text {st }}$ century, attention is focused on the student and what the student can learn. Education is learner-centred and school libraries enhance this trend to help educators to achieve their objectives. The standard for learners requires school libraries to help the learners use skills, and resources and tool to:

- Inquire, think critically and gain knowledge;

- Draw conclusion, make informed decision, apply knowledge to new situations and create new knowledge;

- Share knowledge and participate ethically and productively as members of democratic society;

- Pursue personal and aesthetic growth (Encyclopedia of Library and Information Science, 2010). School library in the new millennium has become information centre because of its method of packaging information through the use of ICT (Daniel, 2000).

In recent times, the school library is a media resource centre where the book and non-book materials are provided. Emphasis is now placed on the provision and dissemination of information through new media (application of information and communication technology). The school library, not only stores information but is also concerned to a large extent with the provision of space for learning and environment for teaching and learning. The school library is a learning laboratory that plays the role of bringing teachers and students together to explore the wealth of knowledge made available in the library. The traditional school library only collects and stores books but the modern school library makes effective use of the new media and ensures that the vast resources available in school libraries are utilized effectively by both students and teachers. As a laboratory, teaching and learning takes place within the confines of the library. The emphasis is on modern philosophy of education that is learner-centred. It emphasizes individualized instruction and the use of multimedia in teaching and learning.

Elaturoti (1990) lent credence to the present educational system, when he stated that modern philosophy of education recognizes an educated individual as one who knows how to learn, to think and to use ideas as opposed to one who has memorized facts. This implies that instructional methods within the curriculum of any educational system that is guided by this philosophy will of necessity stress individual learning and independent study, and students having access to multimedia to meet their individual needs.nAccording to Salawu (2008) learning without borders involves international or global integration of the society. It provides a learning environment that makes a student to participate and contribute towards development of the world. Learning without borders is about internationalizing learning. It is the conscious integration of global awareness in student learning. In the process of learning without borders or internationalizing learning, the students are expected to identify, describe and explain global and intercultural conditions and interdependencies. The students engage in critical thinking that embraces analysis and interpretation of global and cultural issues. The students are also expected to learn effective communication with members of other cultures especially in a fast changing and globalised society.

Our world is being changed dramatically by the surge in technology and communication and the world is changing, and there is evidence that we are entering a "post-international environment" (Davy, 2011). In the same vein, libraries are continually being influence by the changes of technological development and school libraries are no exception. Globalization and technological advances also affect the ways in which education is provided (Australian school library Association, 2013). As noted by Sauers (n.d.), there are many borders when it comes to traditional library services, whether that border is caused by forcing the user to come into a building in order to have their question answered or if it's that large pieces of wood we call a reference desk creating barrier between the librarian and the user, borders are all around us. However, with new and emerging technologies, the dynamics of how information is accessed and utilized has changed (ASLA, 2013). Nevertheless, in the midst of the technological transformation cutting across the globe, it is pertinent that school librarianship must be repositioned to align with trends of contemporary society. This paper therefore is aimed at exploring how school libraries can be repositioned to ensure that learning without borders is actualized. It will highlight the role of school libraries in learning without borders, strategies for repositioning school libraries towards achieving 
learning without borders and the challenges of learning without borders in Nigeria and other developing countries.

\section{THE ROLE OF SCHOOL LIBRARIES IN LEARNING WITHOUT BORDERS}

The role of school library in the $21^{\text {st }}$ century is succinctly captured by Rosa and Storey, 2016) as: i) Offering a full range of print and electronic resources that provide equal learning opportunities for all students regardless of the socio-economic or the educational level of the community;

ii) ensuring that $21^{\text {st }}$ century information literacy skills, dispositions, responsibilities and assessments are integrated throughout all curriculum;

iii) serving the schools student, staff and other members of the learning community.

IFLA School Library Guideline (2015) identified the following roles of school libraries within a school include the following:

- Resource-based capabilities: This is the ability and disposition related to seeking, accessing and evaluating information and the use of information and communication technology to access information.

- Thinking based capabilities which is the ability of critical analysis

- Knowledge-based capabilities: This is the ability related to research and enquiry

- Reading and literacy: This is ability related to enjoyment of reading and reading for pleasure.

- Personal and interpersonal capabilities: This involves the abilities related to social and critical participation in resource-based enquiry and learning about oneself and others.

$\circ \quad$ Learning management capabilities entails abilities and depositions that enable students to prepare for, plan and successfully undertake a curriculum based inquiry unit.

A school librarian plays a leadership role in developing these capabilities. The roles of school libraries stated above enhance the capabilities of globalization of learning without borders. The roles of the school library is aimed at enhancing information literacy capabilities of the students, stimulate reading habit, curiosity, creativity orientation towards learning, explore diverse topics, creation, representation and sharing of knowledge, technology, and access to cultural, professional and educational events. The school library provides space for physical and digital access to resolves and support students, teachers and the learning community. A school library is important to education and learning because it helps students to have knowledge to contribute towards the development of the society and the world.

There is a paradigm shift from the arm chair librarian to information professional who provides information services to the clientele in different locations at the same time (Adebowale, 2010).

\section{STRATEGIES FOR REPOSITIONING SCHOOL LIBRARIES TOWARDS ACHIEVING LEARNING WITHOUT BORDERS}

Repositioning of school libraries requires addressing the following pertinent issues, especially with references to developing countries.

i. Personnel issues: addressing personnel issue in school librarianship is of paramount importance to ensure learning without borders is achieved. Competent personnel should be recruited in school libraries. Competency is not just in theoretical and practical-based librarianship knowledge but must be combined with ICT library skills which are key driver of the digital economy. For school libraries to effectively interact with other institutions and information agencies there is need for such libraries to be managed by ICT- compliant libraries.

ii. Extensive lobbying and advocacy: managers of school libraries should be ready to adopt and apply intensive lobbying and advocacy as means to attract government attention as well as donor agencies. Positioning school libraries towards borderless learning cannot be realistic, if school library managers do not lobby and advocate for school library funding. It is important that school librarians that are good strategist should be engaged to lobby and advocate for school libraries as this will help to attract government attention and other donor agencies. 
iii. Partnership with non-government agencies and stakeholders in educational sector: Library managers in school librarianship should endeavor to partner with NGOs and stakeholders in educational sector as it will help in attracting support from these NGOs and stakeholders.

iv. Retraining of existing school library staff: the school library association of different nations should organized workshops, forums and conferences as platforms for training school librarians in the areas of ICTs application to the provision of school library services as means of meeting global realities.

v. Promote access to new content: school libraries can promote access to new content as means of ensuring that learning without borders is actualized. Social media such as Twitter, Google, Youtube, wikis and flickers can be maximally deployed in school librarianship as it has capacity to promote learning without borders. In this case, student, pupils and teachers can easily have access to new content without being in the library physically.

vi. Through embedded librarians programme: according to Matara, Coffey \& Kushkowski (2010), the increasing availability of online access means that information resources are no longer confined within library walls and librarians need to rethink how their constituent's information needs are being met. In other words, with embedded librarians programme implemented in school librarianship, it would help to ensure that school libraries go beyond the traditional library operations and migrate in the new physical and virtual library services. It thus implies a paradigm shift from the traditional library service to a more innovative and creative virtual library services where physical barriers are eliminated.

vii. Collaboration with other agencies /ICT Services providers: in other to actualize the goal of repositioning school libraries towards learning without borders, collaboration among information providing agencies and ICT services providers is a necessity. As noted by Yates (n.d.), collaboration is a key to enhanced library role in learner engagement which also falls within learning without borders.

\section{THE CHALLENGES OF LEARNING WITHOUT BORDERS IN NIGERIA AND OTHER DEVELOPING COUNTRIES}

1. Lack of skills: The school librarian lacks the skills to select, acquire and disseminate information materials that will equip the students for globalization. There is no staff development because of economic recession and poor leadership. It is important to note that most schools do not have librarians.

2. Lack of infrastructural facilities: learning without borders cannot work without utilization of information and communication technology by teachers, students and the school librarian. In Nigeria the bandwidth is very low and the electricity power generated is less than 2,500 megawatts, the facilities already put in place are deteriorating because of economic down turn. Kalu (2017) believes that because of Nigeria's inability to engage in productive ventures that we may not go out of recession very soon.

3. Lack of interest in the development of school libraries: The government in Nigeria and other developing countries do not give adequate attention to the development of school libraries. School library does virtually not exist in most schools. These schools that have books keep them in boxes. There is no serious legislation directed to the development of school libraries in Nigeria.

4. Funding: In Nigeria, most of the school libraries are owned by the various states of the federation, in fact there is no revenue allocation for the development of school libraries. Even when Nigeria was buoyant, there has never been any serious effort towards the development of school libraries. The Tertiary Education Trust Fund (TETFUND) only provides funds for tertiary institutions in Nigeria.

5. Conformity with global standards copyright and use of information material in the ICT era. The various schools are not involves in acquisition of library materials through online services, so they are not aware of guidelines required in acquisition. The laws available in Nigeria like LRCN laws, National Library of Nigeria law are not implemented with the result.

6. Lack of exchange programmes and detailed curriculum: The developing countries lack the resources to attend exchange programmes to improve the knowledge of the students. The curriculum of schools is not detailed so as to include progarmmes that will expose students to globalization.

7. Lack of ICT equipment and well equipped libraries: The few school libraries available are just book stores. 


\section{CONCLUSION}

School libraries is a pivot on which effective learning at the early stage of a child life resolves, modern infrastructural facilities needs curriculum that reflects $21^{\text {st }}$ century need and school librarians that a possess ICT skills and competencies should be harnessed for achieving learning without walls.

\section{RECOMMENDATIONS ON REPOSITIONING SCHOOL LIBRARIES FOR LEARNING WITHOUT BORDERS}

The role of school libraries in implementation of learning without borders or globalization cannot be over emphasized. It has become necessary to develop and teach skills that will help students, teachers and librarians to have access to information resources. The teachers and students need knowledge of information literacy skills to enable them have access to vast knowledge and information materials that will enable them fit into any society and contribute their quota to the development of the world. The school librarian requires skills that will facilitate utilization of information and communication technology in the selection, acquisition, storage and dissemination of information resources that will encourage globalization.

The government in developing countries should use the tax payers money to provide infrastructural facilities that will facilitate access to current information and effective learning. The bandwidth should be increased and the megawatts for electricity should be increased. Poor power supply is damaging the few facilities available for learning in libraries. The national assembly in Nigeria should make laws that will facilitate provision of infrastructural facilities and the law needs to be implemented and defaulters should be punished accordingly.

Funds should be provided for facilities and provision of current information materials in school library that will help in teaching and learning in schools. The government should make a law that empowers Universal Basic Education Board, to make revenue allocation, for developing of school libraries. There is need to implement the law and the government officials who divert public funds should be punished as a deterrent to others.

The librarians and other information providers should conform to global laws guiding use of information resources to enable them have access to vast library materials for learning. The Librarians Registration Council of Nigeria (LRCN) should be alive to its responsibility of ensuring that librarians are qualified and have the capability of providing services to users.

The curriculum in developing countries should be reviewed. There is need to incorporate critical thinking skills, ICT skills and culture of other societies to facilitate learning without borders. There is need for exchange programmes. The students need to engage in exchange programmes that will enable them know what is happening in other societies.

\section{REFERENCES}

Adebowale, T. O. (2010). The role of the school librarian in the digital age Owena Journal of Library and Information Science, 3(2), 127-128.

Attama, R. O. (2014) Repositioning the school library in support of the Universal Basic Education (UBE) programme in Nigeria. The Nigerian Library Links, 11(2), 58-60.

Australian School Library Association (2013). Future learning and school libraries. ASLA, Canberra, Act.

Daniel, C. I. (2000). Information agenda for school libraries in new millennium. Paper presented at the Annual National Conference AGM of Nigerian Library Association held at Chelsea Hotel Abuja, June 25-30.

Davy, I. (2011). Learners without borders: curriculum for global citizenship. 13 Position Paper. International Baccalaureate Organization.

Elaturoti, D. F. (1990). Developing school library media resources centre. Ibadan: Onibonoje.

Freeman, P. (1975) Pathfinder: an operational guide for school libraries. New York: Harper and Row. 
George, A. (2011). The school library in a mega city setting: The case of Lagos State. Gateway Library Journal, 14(1), 76-86.

Harrods Librarians Glossary. (2015). Edited by Ray Prytherch with edition England: Ashgate and Gower.

IFLA. (2015). IFLA School Library Guidelines. ( $2^{\text {nd }}$ rev. ed.). The Hague, Netherlands: International Federation of Library Associations.

Matara, T., Coffey, D. \& Kushkowski, J. D. (2010). Beyond library walls: embedded librarians in academic departments. http:/lib.dr.iastate.edu/refinst-pubs/32.

Rosa, K. and Storey, T. (2016) American libraries in 2016: creating the future by connecting, collaborating and building community. IFLA Journal, 42(2), 88-89.

Salawu, B. A. (2008). Globalization challenges and opportunities for Nigerian Libraries. Libraries without borders: Globalization of library and information services. Paper Presented at the $46^{\text {th }}$ National Conference and Annual General Meeting of the Nigerian Library Association held at Arewa House Conference Centre Kaduna from 1 - 6 June. Abuja: Nigerian Library Association and HEBN Publishers.

Sauers, M. (n.d.). Library 2.0: creating a borderless library. Urbana-Campaign, IL: University of Illinois.

Yates, F. (n.d.). Beyond library space and place: creating a culture of community engagement through library partnership, Indiana Libraries, 33(2), 53-56. 